\title{
Ras-Related Protein Rab-40B
}

National Cancer Institute

\section{Source}

National Cancer Institute. Ras-Related Protein Rab-40B. NCI Thesaurus. Code C104560.

Ras-related protein Rab-40B (278 aa, $\sim 31 \mathrm{kDa}$ ) is encoded by the human RAB40B gene.

This protein may be involved in the regulation of ubiquitination and vesicle transport. 